\title{
Influence of spirulina intake on metabolism of exercised rats*
}

Gustavo Puggina Rogatto, Camila Aparecida Machado de Oliveira, Júlio Wilson dos Santos,

Fúlvia de Barros Manchado, Fábio Yuzo Nakamura, Camila de Moraes, Alessandro de Moura Zagatto,

Marcel Cardoso Faria, Márcia Afonso and Maria Alice Rostom de Mello

\section{ABSTRACT}

In this study we compared the metabolic response to acute exercise among rats fed on a standard diet or on a spirulina diet. Young Wistar rats were divided into two groups according to diet: control (C) (standard diet) and spirulina (S) (spirulina diet). At the end of experimental period ( 5 weeks) rats were submitted to an acute exercise session of swimming (20 minutes, supporting a load corresponding to $5 \%$ of body weight) to determine blood lactate and serum glucose, insulin, proteins, albumin and fatty free acids (FFA). Gastrocnemius and liver samples were used to determine glycogen and lipids tenors. Both $\mathrm{C}$ and $\mathrm{S}$ groups showed increase in serum glucose and FFA, a drop in serum insulin and a decrease of muscle and liver glycogen contents after acute exercise. Blood lactate during exercise was higher in $\mathrm{S}$ than $\mathrm{C}$ rats. It was concluded that the response pattern to acute exercise was similar for $\mathrm{C}$ and $\mathrm{S}$ rats. However, diet protein seemed to influence aspects of glucose metabolism.

\section{INTRODUCTION}

The protein malnutrition is a public health problem that has affected a large parcel of the world population for many years, especially in the developing countries ${ }^{(1-4)}$. In Brazil, even regions considered as rich such as the Southeast region present significant malnutrition prevalence $(6 \%)^{(5)}$. In states from the Northern and Northeast regions these indexes are even higher, reaching $17 \%$ of population under 5 years of age.

The growth involvement is a consequence frequently observed in individuals in the development phase submitted to situations where the lack of nutrients is present, especially nutrients of protein origin(6). However, other harmful effects that increase the infant mortality rate and impair mental development and maturation demonstrate the risk that the protein-calorie deficiency may cause to malnourished infants ${ }^{(2)}$.

Regardless the malnutrition cause, the organism generates adaptive responses to long periods in which it is submitted to such condition. With regard to the use of energetic substrates, studies report decrease on the energy expenditure when the energy intake is reduced(2). This self-modulation between intake and expenditure is maintained until the moment where the energy expenditure cannot be compensated by the insufficient ingestion. Thus, the organism makes use of its fat supplies, what results in decrease on adiposity and loss of weight. The carbohydrates and proteins metabolism is also influenced by the lack of protein in diet, presenting reduction on glycogen and proteins supplies in muscle

\footnotetext{
* University of the State of São Paulo, Rio Claro-SP.

Received in 6/2/04. $2^{\text {nd }}$ version received in 26/4/04. Approved in 2/5/04
}

Correspondence to: Gustavo Puggina Rogatto, Rua Padre Ferraz, 427 13970-250 - Itapira, SP. Tels.: (65) 9976-2499/(19) 3863-2328, e-mail: grogatto@hotmail.com
Key words: Spirulina. Metabolism. Exercise. Rats. Body growth.

and liver ${ }^{(7-11)}$. Concomitantly, higher concentrations of hepatic fats may be observed in malnourished individuals in function of the lack of fat transportation out of the liver ${ }^{(12,13)}$. These and other negative effects indicate the need of new alternative for the control and fight against this serious problem, which is the protein-energy malnutrition (PEM).

The conventional agriculture, despite the available technology, presents limitations in its capacity of providing sufficient energy for the world population ${ }^{(14)}$. The protein malnutrition problem has concerned public health authorities for many decades, especially the World Health Organization (WHO), which technicians have discussed on new protein sources as well as on norms to be adopted for the use in human alimentation. In this context, microorganisms have received special attention as alternative sources of protein in diet.

Among the several microorganisms that have been studied, the bluish-green seaweed spirulina is considered a promising microorganism due to its high protein content (65 to $70 \%$ of its dried weight) and plentifulness of vitamins and minerals ${ }^{(14,15)}$.

The spirulina is a helicoidal-shaped bluish-green seaweed with $0.2-0.5 \mathrm{~mm}$ of length ${ }^{(16)}$. The seaweed usually grows in waters of lakes naturally alkaline localized in arid zones. Although water from these lakes cannot be used in irrigation, it may be used for the cultivation of spirulina(17). Since this seaweed presents fast reproduction rate, dividing itself three times a day, an area exclusively aimed at the spirulina growth may produce 125 times more protein if compared to an area of the same size aimed at the corn crop or 70 times more protein if compared to the cattle breeding ${ }^{(17)}$. Furthermore, the spirulina presents some advantages in relation to other seaweeds among which we could mention the pleasant taste; spirulina presents no problems with digestion and no toxicity to humans, what does not occur to other seaweeds such as Chlorella and Scenedesmus ${ }^{(14)}$. Spirulina also presents antioxidant and hypocholesterolemic actions ${ }^{(18)}$.

Such as the malnutrition, the physical exercise is a condition where modifications on the general metabolic profile are observed, occurring mobilization on the energetic substrate supplies and alterations in the hormonal secretions ${ }^{(19,20)}$. The acute responses to the aerobic stimulus by means of the physical exercise have been reported in specific literature, recording maintenance or decrease on supplies of lipidic and glycidic substrates during exercise in different experimental models (sedentariness and training, diabetes, obesity) in humans and laboratory animals ${ }^{(21-23)}$. Researches on the effects of the use of spirulina as source of protein are scarce in literature, especially related to physical exercise. Thus, the present study was delineated to evaluate the effects of the ingestion of this seaweed as the only source of protein in diet on the somatic growth and on metabolic responses to acute aerobic exercise in young rats. 


\section{METHODS}

\section{Animals}

For the development of this study, Wistar male young rats (Rattus Norvegicus albinus, Wistar) (approximately 30 days) were used. The animals collected in the Unesp Central Bioterium - Botucatu were maintained in the Bioterium of the Physical Education Department Biodynamic Laboratory - Biosciences Institute - Unesp - Rio Claro. The rats were maintained in collective cages (five rats per cage) in controlled room temperature at $25^{\circ} \mathrm{C}$ and photoperiod of $12 \mathrm{~h}$ light/12 h dark (7 am/7 pm) and water "ad libitum". All procedures to which animals were submitted were in agreement with norms of animal experimentation proposed by the "International Guiding Principles for Biomedical Research Involving Animals".

\section{Experimental groups}

The animals were randomly distributed in the following experimental groups:

Control (C): Animals fed on standard diet (casein as source of protein) during five weeks.

Spirulina (S): Animals fed on manipulated diet (spirulina as source of protein) during five weeks.

Diet compositions are presented in table 1.

\begin{tabular}{lcc} 
& $\begin{array}{c}\text { BOARD } \mathbf{1} \\
\text { Diets composition }\end{array}$ \\
\multicolumn{1}{c}{ Component } & $\begin{array}{c}\mathbf{1 7 \%} \text { protein* } \\
\text { (casein) }\end{array}$ & $\begin{array}{c}\mathbf{1 7 \%} \text { protein } \\
\text { (spirulina) }\end{array}$ \\
Spirulina (65\% protein) & - & $280.0^{* *}$ \\
Casein (84\% protein) & $202.0^{* *}$ & - \\
Corn starch & 397.0 & 386.0 \\
Dextrin & 130.5 & 130.5 \\
Sucrose & 100.0 & 100.0 \\
Soy oil & 70.0 & 70.0 \\
Fiber & 50.0 & 50.0 \\
Mineral mixture* (AIN-93) & 35.0 & 35.0 \\
Vitamins mixture* (AIN-93) & 10.0 & 10.0 \\
L-cystine & 3.0 & 3.0 \\
Choline chlorydrate & 2.5 & 2.5 \\
\hline
\end{tabular}

* According to Reeves et al. ${ }^{(24)}$.

** Values adjusted according to protein content in casein and spirulina.

\section{Procedures}

During all experimental period the animals were weekly weighted and measured. The daily alimentary ingestion was evaluated and the alimentary efficiency was calculated through the following equation:

$$
A E=\frac{(W E-W B)}{T F}
$$

Where:

AE: alimentary efficiency

WE: body weight at the end of the experiment $(\mathrm{g})$

WB: body weight at the beginning of the experiment $(\mathrm{g})$

TF: total amount of food ingested during experiment

In the last week, animals from both groups were again divided into subgroups: CR (control rest); CE (control acute exercise); SR (spirulina rest); SE (spirulina acute exercise), according to the performance or not of an acute session of exercise shortly before sacrifice.

\section{Acute physical exercise}

After a adaptation period in the liquid mean (five minutes of partial immersion in water with no use of the load at the three days prior to test), animals from groups CE and SE were submitted to a physical exercise session composed of 20 minutes of swimming in a water tank supporting load equivalent to $5 \%$ of the body weight of each animal attached to the thorax.

The water temperature was kept between $30^{\circ} \mathrm{C}$ and $32^{\circ} \mathrm{C}$ for being considered as thermally neutral in relation to the rat's body temperature ${ }^{(25)}$.

During the performance of the swimming session, blood samples were collected through cut at the distal extremity of tail of the resting animals and at 5, 10, 15 and 20 minutes of exercise for the determination of the lactate concentration. The lactate was determined in a electrochemical analyzer YSL 2300 STAT (Yellow Springs, Inc. USA).

\section{Animals' sacrifice and biochemical analyses}

At the end of the experimental period, the animals were sacrificed through decapitation without previous fasting. The sacrifice of the rats from control and spirulina groups occurred in rest conditions or after the performance of acute exercise session of swimming.

Blood samples from trunk were collected in glass tubes without anticoagulant for the evaluation of glucose (glucose-oxidase enzymatic method)(26), albumin, proteins, free fatty acids ${ }^{(27)}$ and seric insulin (radioimmunoassay- Kit Coat-A-Count, USA).

A median incision was performed in the back and front paw for the removal of sample from the gastrocnemius muscle. The sample was weighted and used for analysis of the glycogen concentration through colorimetric method(28,29). Liver samples were used for the dosage of glycogen ${ }^{(28,29)}$ and lipids ${ }^{(27)}$, also through colorimetry.

All biochemical determinations were performed by a specialized technician who had no access to information with regard to allocation of animals to the respective groups.

\section{Statistical analysis}

The results were expressed as average \pm standard deviation and statistically analyzed through t-Student test for independent samples, Analysis of Variance and post-hoc Bonferroni test. In all cases, the significance level was established in $5 \%$.

\section{RESULTS}

\section{Parameters evaluated during experimental period}

In table 1, different results of body weight, body length and food ingestion of animals from control and spirulina groups during the five weeks of treatment are found. Both groups presented significant increase on body weight after the first week of study and no differences between groups were observed. With regard to the body length, both groups presented significant weekly growth until the end of the experiment from the second week on. However, such as weight, the body length showed no difference between control and spirulina groups. No significant differences were observed in food ingestion when groups were compared. The alimentary efficiency of control group was also similar to the spirulina group (figure 1).

The blood lactate concentrations are presented in figure 2. Both animals from control and spirulina groups presented significant increase on this metabolite during performance of the load test. However, for animals from spirulina group, this increase was more intense at the $20^{\text {th }}$ minute $(p<0,05)$.

\section{Parameters evaluated after sacrifice}

In the present study, 30 animals from each group were considered for the evaluation of the pre-sacrifice parameters (weight, length, ingestion and alimentary efficiency). However, in function of the experiment continuity and other evaluations, only eight animals from each group were sacrificed for the attainment of biological material for the present study. 
TABLE 1

Weight $(\mathrm{g})$, body length $(\mathrm{cm})$ and food ingestion in $24 \mathrm{~h}(\mathrm{~g} / 100 \mathrm{~g} \mathrm{b.w})$ of animals during experiment

\begin{tabular}{|c|c|c|c|c|c|c|}
\hline & Initial & $1^{\text {st }}$ week & $2^{\text {nd }}$ week & $3^{\text {rd }}$ week & $4^{\text {th }}$ week & $5^{\text {th }}$ week \\
\hline \multicolumn{7}{|l|}{ Weight } \\
\hline Control & $254.5 \pm 28.1$ & $290.8 \pm 32.1^{a}$ & $329.9 \pm 29.7^{a, b}$ & $351.3 \pm 29.7^{a, b}$ & $368.4 \pm 33.5^{a, b, c}$ & $392.8 \pm 29.0^{a, b, c}$ \\
\hline Spirulina & $254.7 \pm 21.6$ & $286.0 \pm 26.0^{a}$ & $315.6 \pm 34.6^{a, b}$ & $345.8 \pm 25.0^{a, b, c}$ & $362.9 \pm 29.4^{a, b, c}$ & $379.1 \pm 27.7^{a, b, c}$ \\
\hline \multicolumn{7}{|l|}{ Length } \\
\hline Control & $20.7 \pm 1.2$ & $21.6 \pm 1.2$ & $22.5 \pm 1.3^{a}$ & $23.1 \pm 1.3^{a, b}$ & $23.9 \pm 1.0^{a, b, c}$ & $24.4 \pm 0.8^{a, b, c}$ \\
\hline Spirulina & $20.7 \pm 1.1$ & $21.6 \pm 1.2$ & $22.5 \pm 1.2^{\mathrm{a}}$ & $23.2 \pm 1.2^{a, b}$ & $24.1 \pm 1.1^{a, b, c}$ & $24.6 \pm 1.1^{a, b, c}$ \\
\hline \multicolumn{7}{|c|}{ Food ingestion } \\
\hline Control & $11.3 \pm 3.1$ & $8.2 \pm 1.1$ & $7.4 \pm 1.7^{a}$ & $7.6 \pm 1.2^{\mathrm{a}}$ & $7.0 \pm 1.6^{a}$ & $5.0 \pm 1.1^{a}$ \\
\hline Spirulina & $9.0 \pm 2.2$ & $7.6 \pm 1.1$ & $7.5 \pm 2.4$ & $6.8 \pm 1.4$ & $6.7 \pm 1.3$ & $5.1 \pm 1.2^{\mathrm{a}}$ \\
\hline
\end{tabular}

Results expressed as average \pm standard deviation, $n=30$ per group a. $\neq$ initial; $b . \neq 1^{\text {st }}$ week; $c . \neq 2^{\text {nd }}$ week.

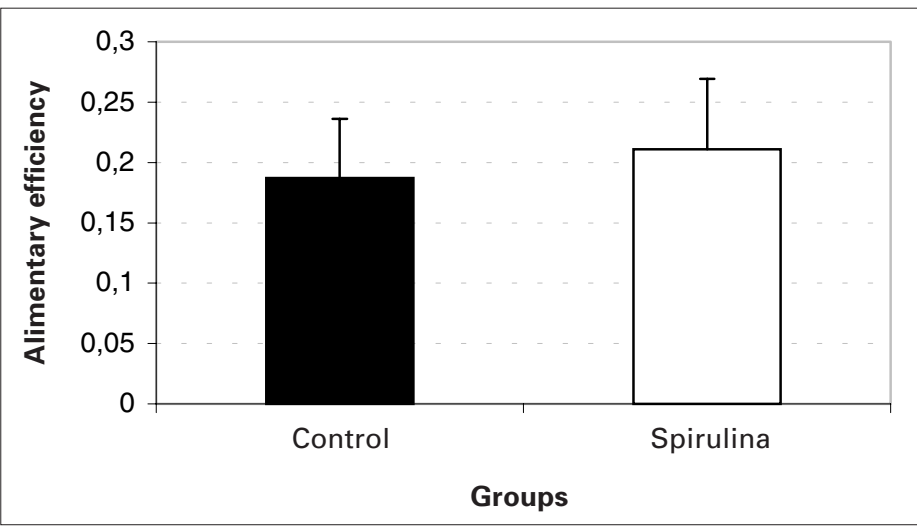

Fig. 1 - Alimentary efficiency (weight gain/amount of food ingested) during experiment. Results expressed as average \pm standard deviation, $n=30$ per group.

\section{TABLE 2}

Seric parameters of animals in rest at the end of experiment (CR and SR) and after a single session of exercise (CE and SE)

\begin{tabular}{lccccc}
\hline Groups & $\begin{array}{c}\text { Glucose } \\
(\mathbf{m g} / \mathbf{d L})\end{array}$ & $\begin{array}{c}\text { Insulin } \\
(\boldsymbol{\mu} \mathbf{U l} / \mathbf{m L})\end{array}$ & $\begin{array}{c}\text { Proteins } \\
(\mathbf{g} / \mathbf{d L})\end{array}$ & $\begin{array}{c}\text { Albumin } \\
(\mathbf{g} / \mathbf{d L})\end{array}$ & $\begin{array}{c}\mathbf{A G L} \\
(\mathbf{m E q} / \mathbf{m L})\end{array}$ \\
$\mathrm{CR}$ & $82.8 \pm 12.8$ & $11.0 \pm 3.2$ & $7.3 \pm 0.2$ & $6.0 \pm 0.6$ & $0.49 \pm 0.11$ \\
$\mathrm{CE}$ & $137.4 \pm 31.5^{\mathrm{a}}$ & $3.6 \pm 1.4^{\mathrm{a}}$ & $7.4 \pm 0.3$ & $5.6 \pm 0.6^{\mathrm{a}}$ & $0.60 \pm 0.06^{\mathrm{a}}$ \\
$\mathrm{SR}$ & $73.0 \pm 11.7$ & $13.1 \pm 4.5$ & $7.9 \pm 0.4$ & $5.4 \pm 0.3$ & $0.44 \pm 0.07$ \\
$\mathrm{SE}$ & $117.0 \pm 23.8^{\mathrm{a}, \mathrm{b}}$ & $3.3 \pm 1.1^{\mathrm{a}, \mathrm{b}}$ & $7.6 \pm 0.5$ & $6.0 \pm 0.4^{\mathrm{b}, \mathrm{c}}$ & $0.56 \pm 0.06^{\mathrm{b}}$ \\
\hline
\end{tabular}

Results expressed as average \pm standard deviation, $\mathrm{n}=8$ per group.

$\mathrm{C}=$ control; $\mathrm{S}=$ spirulina; $\mathrm{R}=$ rest; $\mathrm{E}=$ acute exercise. $\mathrm{a} . \neq \mathrm{CR} . \mathrm{b} . \neq \mathrm{SR} . \mathrm{c} . \neq \mathrm{CE}$

Table 2 presents the glucose seric concentrations, insulin, total proteins, albumin and free fatty acids (FFA) of animals from control and spirulina groups in conditions of rest and after a 20-minutes exercise session of swimming. An increase on the glycemia due to the acute effect of the effort was observed, being less evident in the spirulina group. The only exercise session resulted in reduction of the insulin seric concentrations in both experimental groups. No significant differences were observed in the protein concentration due to both the diet action and the performance of the acute exercise. At the end of the effort series, both experimental groups presented modifications in the serum albumin as follows: reduction for the control group and increase for the spirulina group. With regard to the free fatty acids, the acute exercise alone caused significant alterations, resulting in increase on this lipidic substrate.

The hepatic and muscular glycogen content and the lipid concentrations in liver are recorded in table 3. Both liver and muscle carbohydrate contents presented similar behavior due to the acute exercise performance and due to the diet modification. After the performance of the swimming series, both organs presented significant decrease in supplies of this energetic substrate and it was more intense in the spirulina group. No alterations in the hepatic lipids contents were observed.

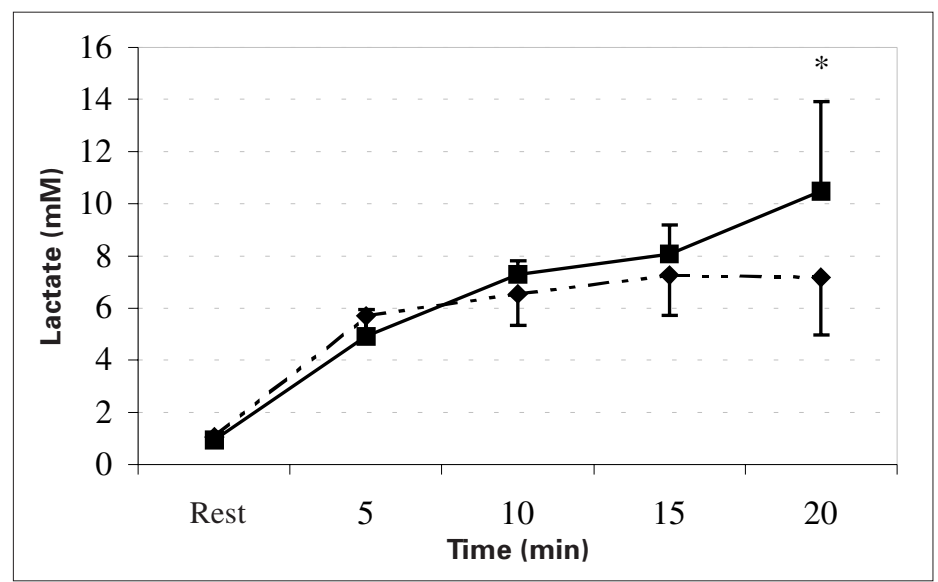

Fig. 2 - Blood lactate in rest situation $(R)$ and during 20 minutes of swimming exercise with loads corresponding to $5 \%$ of the body weight. Broken line (---) control group; constant line (-) spirulina group. * Significant difference between groups in T20. $N=8$ animals per group.

TABLE 3

Hepatic glycogen $(\mathrm{mg} / 100 \mathrm{mg})$, hepatic lipids $(\mathrm{mg} / 100 \mathrm{mg}$ ) and muscular glycogen $(\mathrm{mg} / 100 \mathrm{mg}$ ) of animals in rest at the end of experiment (CR and SR) and after a single session of exercise (CE and SE)

\begin{tabular}{cccc}
\hline Groups & $\begin{array}{c}\text { Hepatic glycogenic } \\
\text { (mg/100 } \mathbf{~ m g )}\end{array}$ & $\begin{array}{c}\text { Hepatic lipids } \\
\mathbf{( m g / 1 0 0} \mathbf{~ m g})\end{array}$ & $\begin{array}{c}\text { Muscular glycogenic } \\
\text { (mg/100 } \mathbf{~ m g})\end{array}$ \\
CR & $9.21 \pm 1.30$ & $6.64 \pm 1.33$ & $0.57 \pm 0.07$ \\
CE & $6.93 \pm 0.97^{\mathrm{a}}$ & $6.41 \pm 1.45$ & $0.29 \pm 0.05^{\mathrm{a}}$ \\
SR & $11.45 \pm 2.05^{\mathrm{a}}$ & $6.62 \pm 1.30$ & $0.70 \pm 0.14^{\mathrm{a}}$ \\
$\mathrm{SE}$ & $5.23 \pm 1.48^{\mathrm{a}, \mathrm{b}, \mathrm{c}}$ & $7.49 \pm 1.11$ & $0.18 \pm 0.06^{\mathrm{a}, \mathrm{b}, \mathrm{c}}$ \\
\hline
\end{tabular}

Results expressed as average \pm standard deviation, $\mathrm{n}=8$ per group.

$\mathrm{C}=$ control; $\mathrm{S}=$ spirulina; $\mathrm{R}=$ rest; $\mathrm{E}=$ acute exercise. $\mathrm{a} . \neq \mathrm{CR} . \mathrm{b} . \neq \mathrm{SR} . \mathrm{c} . \neq \mathrm{CE}$.

\section{DISCUSSION}

The utilization of spirulina as food has been exhaustedly discussed in specific literature ${ }^{(14,30-32)}$. Besides being a good source of proteins, minerals and vitamins, the spirulina presents no toxicity to humans and no impairments to the development of organs and tissue $^{(14,31)}$. In our study, no alterations in weight and body length were observed in animals fed on spirulina-based diet when compared to control group. Furthermore, the ingestion values and alimentary efficiency were also similar between both nutritional conditions (control and spirulina), indicating that this alternative source of protein originated from biomass does no impair the growth of animals in the development phase. These results corroborate reports from literature that compare diets based on spirulina and casein ${ }^{(14)}$ and spirulina and "pellet"(30). The utilization of young animals (30 days at the beginning of experiment) may explain the reduction of the amount of food ingested along the study, once as animals aged, the nutrients requirements for the somatic development may have been decreased. Through evaluations performed 
in the present study, it was not possible to determine the reasons why animals from control group presented reduction on the amount of food ingested along the experiment before animals from spirulina group.

In our work, the performance of physical exercises furthered alterations on the blood lactate concentrations in both groups, indicating an acute metabolic stress condition. During the performance of the physical exercise, an increase on the exigency of several organic systems was observed, resulting in the activation of mechanisms related to the mobilization of energetic substrates. Such response facilitates the redistribution of these fuels in the organism aimed at the maintenance of the muscular work. When this demand exceeds the oxygen supply or its utilization rate, the energetic contribution through the anaerobic via of the carbohydrate metabolism becomes higher, what produces an excess of hydrogen ions that combine with pyruvic acid to form lactic acid. Later, it diffuses into the blood, being converted into lactate ${ }^{(33)}$. The lactate produced plays important role in the energy supply, once it may be reconverted into glucose by the liver ${ }^{(34)}$. The blood lactate concentrations during the first 15 minutes of swimming (acute test) were similar between control and spirulina groups (figure 2). Only at the $20^{\text {th }}$ minute, a more intense elevation was observed in the group fed on spirulina-based diet. Probably, the groups exercised in different effort domains. According to Gaesser and Poole ${ }^{(35)}$, the exercise intensities in which an elevation of the blood lactate concentration above the rest values is detected, however, with stabilization in some moment of the load, belong to the intense effort domain. The upper limit of this domain is the intensity corresponding to the lactate maximal stable state or anaerobic threshold. The effort intensities above the anaerobic threshold would cause a continuous increase on the blood lactate concentration, hastening fatigue as result of the metabolic acidosis. These intensities are found in the effort severe domain. It is believed that in this effort domain, the $\dot{\mathrm{VO}}_{2}$ would invariably reach its maximal value. Thus, according to results of figure 2, we could suppose that rats belonging to control group would be exercising in the effort intense domain. In other words, swimming with additional overload of $5 \%$ of the body weight would not be sufficiently intense to cause an elevated acidosis, neither a maximal cardio respiratory response (inferred due to the verification of the $\dot{\mathrm{V}} \mathrm{O}_{2 \max }$ ). Animals belonging to the spirulina group would be, during the acute test, performing severe exercise, once there is no evidence of the blood lactate stabilization, particularly at the five final minutes of effort, where the metabolite concentration suffered elevation of $2.4 \mathrm{mM}$. Some authors ${ }^{(36)}$ accept that an elevation lower than 1 $\mathrm{mM}$ during the last 20 minutes of rectangular load of 30 minutes would be a good indicative of lactate stable state. According to this interpretation, animals fed on spirulina would be impaired on the development of their aerobic capacity if compared to animals from the control group along their growth and development, once when submitted to the same relative swimming load, they would present physiological responses that indicate higher organic overload (acidosis).

The glycemic response during and after the performance of acute exercise in rats has varied in function of differences in the activities employed. The performance of the swimming exercise with loads that ranged from 0 to $8 \%$ in relation to the body weight for 30 or 60 minutes in some cases resulted in no modifications on the glycemic profile in acute condition ${ }^{(37-39)}$. Nardo and Luciano(40) have also observed reductions on glycemia after acute performance of aerobic effort. In these cases, the increase on the catching of glucose by peripheral tissues during exercise may be the factor responsible for the glycemic drop(41). On the other hand, increases on the glucose seric concentrations were verified in our work what is in agreement with previous findings ${ }^{(19,20,37)}$. This hyperglycemic response was observed in both the control group and the spirulina group and it is possibly related to the increase on the sympathetic activity with consequent increase on the muscular and hepatic glycogenolytic activity. Mechanisms involved with the neoglycogenesis may also be contributing to the increase on the glycogen content in function of elevations on the glycocorticoid hormones secretion ${ }^{(42)}$. Furthermore, several studies have reported increase of the secretory responses of other contraregulatory hormones such as the growth hormone and catecholamines, among others after acute exercise ${ }^{(43-50)}$.

The lowering on the insulin-induced seric concentration due to effort acute performance observed in both groups of our study is in agreement with previous works that used continuous and intermittent exercises $(19,20,48)$. The sympathetic stimulation as result of the effort acute performance may have resulted in the inhibition of the insulin release in that, in addition to the increase on the secretion of the contraregulatory hormones contributed to the glycemia elevation in both experimental groups.

The lipidic metabolism may also suffer interference from the physical activity, once the mobilization of this type of substrate may be found increased. In our study, the AGL concentration present significant increase after the performance of a single session of effort in both the group fed on standard diet and the group fed on spirulina. This result may indicate increase on the mobilization of triglycerides stocked in the adipocites, what is in agreement with previous works ${ }^{(51)}$ and may be related to elevations on increase on the secretion of the contraregulatory hormones. The quality of the protein ingested seems not to influence the concentration of this lipidic substrate.

The evaluation of the total proteins and seric albumin may be used as indicative of the presence of protein malnutrition, once organisms such as Kwashiorkor present significant reduction on these components ${ }^{(4)}$. Thus, the fact that the reduction on the blood proteins in the group fed on spirulina diet had not been verified is an evidence that this diet consists of a source of protein adequate for the development of young animals. Influences on the acute physical activity on the albumin profile were observed, which suffered reduction and increase in groups control and spirulina, respectively. A hypothesis for this type of response may be related to modifications on the organism's catabolic activity before acute activity, generated by the ingestion of spirulina, aiming at accelerating the muscular and hepatic proteins mobilization with increase on the availability of albumin in circulatory system.

The hepatic steatosis or the lipids accumulation in liver is a metabolic alteration that has also been observed in organisms submitted to chronic protein-energy malnutrition ${ }^{(13,52)}$. This increase of fat concentration in liver mainly occurs in function of the increase on the triglycerides content ${ }^{(13,53)}$. In our study, no difference in the hepatic content of lipids in both nutritional and exercise conditions was observed. In previous studies, an increase on the activity of the lipoproteic lipase enzyme in liver of animals fed on spirulina was observed(54).

The intermediate metabolism plays important role in the maintenance of the organic homeostasis, contributing with the supplying of energy in normal conditions or in situations where the metabolic requirement is found increased. The acute physical exercise is a type of stimulus that requires higher mobilization of the energetic substrate from the organism, including from the carbohydrate supplies ${ }^{(33,55)}$. In our study we could observe that the hepatic and muscular glycogen supplies presented significant reduction after acute exercise in both control diet and spirulina diet groups. This type of metabolic behavior has been frequently observed in several studies that used different forms of physical activity ${ }^{(16)}$. This decrease on the glycogen supplies is related to the elevation of the glycogenolytic activity caused by the acute increase on the catabolic hormones ${ }^{(56)}$, being responsible for the increase on the postexercise glycemia in both groups. We have no consistent explanation for the observation of higher mobilization of the muscular and hepatic glycogen in animals from spirulina group submitted to acute 
exercise, however, mechanisms related to glycogenolysis such as the activity of the glycogenolytic enzymes as well as the adrenergic activity that might be increased in the group fed on this seaweed, are possible explanations for this response. The muscular and hepatic glycogen supplies, significantly higher in animals in rest condition fed on spirulina if compared to animals from control group, may be very important for the maintenance of the homeostasis during exercise in these animals. The set of these results indicates the necessity of further researches in order to clear points yet ambiguous about the effects of the utilization of spirulina as alternative source of protein for organisms in the development phase.

We have come to the conclusion that spirulina did not cause impairments in the growth of rodents as well as in most biochemical parameters analyzed and presented good acceptance by animals. This suggests that this seaweed may be a good alternative source of protein. However, the high blood lactate contents observed during effort test may induce the early fatigue in exercise, what could impair the physical performance. Further studies on the topic will be required in order to elucidate this and other questions that remain answerless.

All the authors declared there is not any potential conflict of interests regarding this article.

\section{REFERENCES}

1. Castro J. Geopolítica da fome. 7ạ ed. Rio de Janeiro: Brasiliense, 1965

2. Torun B, Chew F. Protein energy malnutrition. In: Shils M, Olson JA, Shike M, editors. Modern nutrition in health and disease. Philadelphia: Lea \& Febiger 1994;950-76.

3. Uvin P. The state of world hunger. Nutr Res 1994;52:151-61.

4. Dâmaso A. Nutrição e exercício na prevenção de doenças. Rio de Janeiro: MEDSI, 2001.

5. Ministério da Saúde. Pesquisa nacional sobre demografia e saúde 1996: relatório preliminar. Brasília: Ministério da Saúde, 1996.

6. Frank S. Metabolic adaptation in protein-energy malnutrition. J Am Coll Nutr 1986;5:371-81.

7. Alleyne GAO, Scullard GH. Alterations in carbohydrate metabolism in Jamaican children with severe malnutrition. Clin Sci 1969:37:631-42.

8. Alleyne GAO, Millward DJ, Scullard GH. Total body potassium muscle electrolytes and glycogen in malnourished children. J Pediatr 1970;76:75-81.

9. Waterlow JC, Mendes CB. Composition of muscle in malnourished infants. Nature 1957;180:1361

10. Waterlow JC. The nature and significance of nutritional adaptation. Eur J Clin Nutr 1998:53:52-5.

11. Waterlow JC, Weisz J. The fat protein and nucleic acid of liver in malnourished human infant. J Clin Invest 1956:35:346-54

12. Flores H, Pak N, Maccioni A, Monckeberg F. Lipid transport in kwashiorkor. Br J Nutr 1970;24:1005-11.

13. Kumar V, Deo MG, Ramalingaswami V. Mechanism of fatty liver in protein deficience: an experimental study in the rhesus monkey. Gastroenterology 1972 62:445-51.

14. Contreras A, Herbert DC, Grubbs BG, Cameron IL. Blue-green alga, spirulina, as the sole dietary source of protein in sexually maturing rats. Nutr Rep Int 1979 19:749-63.

15. Kay RA. Microalgae as food and supplement. Food Sci Nutr 1991;30:555-73.

16. Hadenshog G, Haffen AV. The ultrastructure of Spirulina plantensis. Physiol Plant 1970;23:209.

17. Furst PT. Spirulina - a nutricious alga, once a staple of Aztec diet, could feed many of the world hungry people. Human Nature 1978;3:60.

18. Rodriguez-Hernandez A, Blé-Castillo JL, Juárez-Oropeza MA, Diaz-Zagoya JC. Spirulina maxima prevents fatty liver formation in CD-1 male and female mice with experimental diabetes. Life Sciences 2001:69:1029-37.

19. Rogatto GP, Luciano E. Efeitos do treinamento físico intenso sobre o metabolismo de carboidratos. Revista Brasileira de Atividade Física \& Saúde 2001;6:39 46.

20. Rogatto GP, Luciano E. Influência do treinamento físico intenso sobre o metabolismo de proteínas. Motriz 2001;7:75-82

21. Green HJ, Ball-Brunett M, Symon S, Grant S, Jamieson G. Short-term training, muscle glycogen and cycle endurance. Can J Appl Physiol 1995;20:315-24

22. Nakamura M, Brown J, Miller WC. Glycogen depletion patterns in trained rats adapted to a high-fat or high-carbohydrate diet. Int J Sports Med 1998;19:419

23. Romijn JA, Coyle EF, Sidossis LS, Rosenblatt J, Wolfe RR. Substrate metabolism during different exercise intensities in endurance-trained women. J App Physiol 2000;88:1707-14
24. Reeves PG, Nielsen FH, Fahey GC Jr. AIN-93 purified diets for laboratory rodents: final report of the American Institute of Nutrition ad hoc writing committee on the reformulation of the AIN-76 rodent diet. J Nutr 1993:123:1939-51.

25. Azevedo JRM. Determinação de parâmetros bioquímicos em ratos sedentários e treinados, durante e após exercício agudo de natação. Tese de Doutorado. Campinas: Unicamp, 1994

26. Henry RJ, Cannon DC, Wilkeman J. Clinical chemistry, principles and techniques. $2^{\text {nd }}$ ed. New York: Harper and Harper Row Publishes, 1974.

27. Nogueira DM, Strufaldi B, Hirata MH, Abdalla DSP, Hirata RDC. Métodos de bioquímica clínica: técnico-interpretação. São Paulo: Pancasat, 1990.

28. Sjörgreen B, Nordenkjold T, Holmgren H, Wollerstrom J. Bertrag zur kuntnis des leberrhythmik. Pflügers Arch Gesamte Physiol Menschen Tiere 1938;240:247.

29. Dubois B, Gilles KA, Hamilton JK, Rebers PA. Colorimetric method for determination of sugar and related substances. Anal Chem 1965;28:350-6.

30. Tranquille N, Emeis JJ, Chambure D, Binot R, Tamponnet C. Spirulina acceptability trials in rats. A study for the "Melissa" life-support system. Adv Space Res 1994;14:167-70.

31. Salazar M, Martinez E, Madrigal E, Ruiz LE, Chamorro GA. Subchronic toxicity study in mice fed Spirulina maxima. J Ethnophamacol 1998;62:235-41.

32. Grinstead GS, Tokach MD, Dritz SS, Goodband RD, Nelssen JL. Effects of Spirulina plantensis on growth performance of weanling pigs. Anim Feed Sci Technol 2000;83:237-47.

33. McArdle WD, Katch Fl, Katch VL. Fisiologia do exercício: energia, nutrição e desempenho humano. Rio de Janeiro: Guanabara Koogan, 1996.

34. Brooks GA. Ácido láctico no sangue: o "vilão" dos esportes torna-se bom. Sports Science Exchange 1995;2:1-6.

35. Gaesser GA, Poole DC. The slow component of oxygen uptake kinetics in humans. Exerc Sport Sci Rev 1986;24:35-70

36. Heck H, Mader A, Hess G, Mücke S, Hollman W. Justification of the 4-mmol/l lactate threshold. Int J Sports Med 1985;6:117-30.

37. Prada FJA, Carneiro EM, Azevedo JRM, Luciano E. Respostas endócrino-metabólicas em ratos diabéticos: efeito estressor do exercício agudo. Revista Brasileira de Atividade Física \& Saúde 1997;2:22-9.

38. Felício PFV, Drigo AJ, Azevedo JRM. Efeito da administração de ascorbato (vitamina C) associada ao exercício agudo de natação sobre os níveis de substratos energéticos em cobaias. Motriz 1999;5:92

39. Luciano E, Guerino MR, Luciano EA. Influências da atividade física e da aplicação do ultra-som sobre o reparo ósseo em ratos diabéticos. Rev Bras Cien Mov (Edição Especial) 1999;142.

40. Nardo N Jr, Luciano E. Influências do treinamento físico sobre a resposta ao estresse agudo em ratos normais e diabéticos experimentais. Anais do XXI Simpósio Internacional de Ciências do Esporte. p. 105. São Paulo: CELAFISCS, 1998

41. Luciano E, Carneiro EM, Reis MAB, Peres SB, Velloso LA, Boschero AC, Saad MJA. Endurance training modulates early steps of insulin signaling in rat muscle. Med Sci Sports Exerc 1998:30:S24

42. Rogatto GP, Luciano E. Hormonal and metabolic response to acute exercise: effects of high intensity training. Med Sci Sports Exerc 2000;32:S227

43. Jurimae T, Karelson K, Smirnova T, Viru A. The effect of a single-circuit weighttraining session on the blood biochemistry of untrained university students. Eur J Appl Physiol 1990;61:344-8.

44. Tabata I, Atomi Y, Mutoh Y, Miyashita M. Effect of physical training on the responses of serum adrenocorticotropic hormone during prolonged exhausting exercise. Eur J Appl Physiol 1990:61:188-92.

45. Häkkinen K, Pakarinen A. Acute hormonal response to heavy resistance loading in men and women at different ages. Int J Sports Med 1995;16:507-13

46. Gotshalk LA, Loebel CC, Nindl BC, Putukian M, Sebastianelli WJ, Newton RU, et al. Hormonal responses of multiset versus single-set heavy-resistance exercise protocols. Can J Appl Physiol 1997;22:244-55.

47. Ortega E, Rodriguez MJ, Barriga C, Forner MA. Corticosterone, prolactin and thyroid hormones as hormonal mediators of the stimulated phagocytic capacity of peritoneal macrophages after high-intensity exercise. Int J Sports Med 1996; 17:149-55.

48. Kraemer WJ, Hakkinen K, Newton RU, McCormick M, Nindl BC, Volek JS, et al. Acute hormonal responses to heavy resistance exercise in younger and older men. Eur J Appl Physiol 1998;77:206-11.

49. Viru A, Laaneots L, Karelson K, Smirnova T, Viru M. Exercise-induced hormone responses in girls at different stages of sexual maturation. Eur J Appl Physiol 1998;77:401-8

50. Zouhal H, Rannou F, Gratas-Delamarche A, Monnier M, Bentué-Ferrer D, Delamarche P. Adrenal medulla responsiveness to the sympathetic nervous activity in sprinters and untrained subjects during a supramaximal exercise. Int J Sports Med 1998:19:172-6.

51. Stevanato E. Efeitos do jejum sobre a interação entre o metabolismo de ácidos graxos livres e glicose em músculos esqueléticos de ratos treinados. Dissertacão de Mestrado. Rio Claro: Unesp, 1999.

52. Ferro-Luzzi A, Spadoni MA. Protein-energy malnutrition. Prog Food Nutr Sci 1978; 2:515-41.

53. Taylor GO, Ziboh VA. Liver lipid changes in experimental protein malnutrition. Am J Clin Nutr 1972;25:285-90.

54. Iwata K, Inayama T, Kato T. Effects of Spirulina plantensis on plasma lipoprotein lipase activity in fructose-induced hyperlipidemic rats. J Nutr Sci Vitaminol 1990 36:165-71.

55. Fox EL, Bowers RW, Foss ML. Bases fisiológicas de educação física e dos desportos. 4a ed. Rio de Janeiro: Guanabara Koogan, 1991.

56. Guyton AC, Hall JE. Tratado de fisiologia médica. 9a ed. Rio de Janeiro: Guanabara Koogan, 1997. 